\title{
Research on the Training Mode of Graduate Education under the Cooperation of School and Enterprise
}

\section{Lei Fan, Yan Zhou*}

Yanbian University 133002

Supported by the Educational Science Planned Research Project of 13th Five-year Plan of Jilin Province in 2016(Grant No.GH16029), the Educational Science Planned Research Project of 13th Five-year Plan ofJilin Province in 2017 (Grant No. GH170022), the Research Project of Higher Education Research Academy of Jilin Province in 2017(Grant No.JGJX2017C8), the Research Project of Higher Education Research Academy of Jilin Province in 2018(Grant No.JGJX2018D363), the PhD Start-up Fund of Yanbian University(Grant No.602018022), the School-enterprise Cooperation Fund of Yanbian University(Grant No.482019011), Youth Fund Project of Yanbian University(Grant No.602016029), and the Excellent Course Construction Project of Yanbian University.

Abstract: In the process of cultivating graduate students, school-enterprise cooperation has become a new type of training model. Under the conditions of a full understanding of the definition of school-enterprise cooperation, this article combines the characteristics of our country's teaching system to discuss school-enterprise cooperation and develop a graduate training model. In-depth research was carried out, and the problems and countermeasures in the training model were put forward to provide a clear direction for the future development of the teaching system and graduate students.

Keywords: Postgraduate; School-Enterprise Cooperation; Teaching Reform

My country has entered a period of rapid development, and its influence in the world is getting bigger and bigger. With the continuous improvement of national cultural quality, more and more students have entered the ranks of graduate students, which makes all sectors of society attach importance to graduate education The degree has increased significantly. Under the current educational philosophy, for the training of graduate students, in addition to mastering advanced knowledge, it is also necessary to cultivate their innovative abilities so that they can become high-quality talents that are conducive to the country's modernization. The training model of enterprise cooperation is effectively implemented.

\section{Definition of school-enterprise cooperation}

The so-called school-enterprise cooperation refers to the introduction of corporate culture into school teaching. There is no lack of such a phenomenon in society. After graduation, many graduate students find that their knowledge does not play a good role in their work, even if they are professional counterparts. Under the circumstances, many jobs also need to learn from scratch, which means that there is a derailment between the school and the company. In order to make graduate students familiar with the work as soon as possible, it is necessary to integrate corporate culture in the classroom and combine the professional knowledge and employment direction to cultivate.

\section{The significance of school-enterprise cooperation}

The advantage of school-enterprise cooperation is to promote the two-way flow of resources from enterprises and institutions and universities. Graduate students carry out relevant internship and practical activities in enterprises and Copyright (C) 2020 Lei Fan et al.

doi: 10.18282/le.v9i7.1485

This is an open-access article distributed under the terms of the Creative Commons Attribution Non-Commercial License

(http://creativecommons.org/licenses/by-nc/4.0/), which permits unrestricted non-commercial use, distribution, and reproduction in any medium, provided the original work is properly cited. 
conduct research on scientific research projects. On the one hand, they exercise the application and practical ability of graduate students, and at the same time The social benefits of colleges and universities play an important role. In addition, the employment benefits of enterprises and institutions have increased significantly.

The use of school-enterprise cooperation plays an important role in the operating costs of both parties, greatly reducing the efficiency and operating costs of the enterprise, and promoting mutual cooperation between the two parties. Universities can tailor different teaching practices for graduate students according to the requirements of the enterprise The plan is conducive to cultivating high-quality application-oriented talents for students to broaden the employment options, provide more employment opportunities, enterprises also have the opportunity to absorb more professional and high-quality talents, and help enterprises improve their overall strength and market competitiveness.

\section{Problems and countermeasures in the joint training of graduate students by school-enterprise cooperation}

The education and training of graduate students under the cooperation of schools and enterprises often encounter some problems and contradictions in the process of practice. The first is the problem of the faculty of colleges and universities. The current faculty of colleges and universities has been formed in construction, and it is difficult to adapt to the school-enterprise cooperation model in a short time. Most of the current faculty teams pay more attention to the cultivation of graduate students' academic research capabilities, so they often ignore the development of graduate students' practical ability. In addition to sufficient scientific research capabilities and knowledge reserves, enterprises and public institutions need to have strong application and practical capabilities. The stronger the enterprise, the higher the requirements for graduate students. Many companies hope that graduate students will be employed. At this moment, you can make a contribution to the enterprise and can immediately start to complete your own related work, so how to train high-quality, highly educated and strong practical ability is a key work under the school-enterprise cooperation training model.

Secondly, in the face of the changing demand for social talents, the traditional teaching model cannot export applied talents for enterprises. Traditional education models are based on the subject knowledge system, and the teaching content lacks both innovation and contemporary characteristics. However, the ability of graduate students trained under this teaching model cannot meet the real needs of the enterprise. Such universal training will reduce the core competitiveness of graduate students and make their comprehensive ability unable to adapt to corporate positions. Therefore, when conducting graduate education, we should pay attention to social development, grasp the needs of the times and enterprises for talents, and improve the comprehensive quality of students through the transformation of teaching models. The school-enterprise cooperation can strengthen the relationship between the school and the enterprise, fully understand the characteristics of the talents needed by the enterprise, and improve the core competitiveness of graduate students according to the employment needs of the enterprise, so that the ability and academic hours of graduate students can be obtained in specific positions. Fully manifested.

Thirdly, school-enterprise cooperation cannot be superficial. In-depth and scientific cooperation must be carried out to truly enhance the comprehensive ability of graduate students. At present, the school-enterprise cooperation in many regions has formal and superficial problems. The method of school-enterprise cooperation only stays when students go to the company for visits, internships or internships, and students also lack a serious attitude when conducting visits, which is more like going through a formality and going out to school. And this kind of fancy visit has little effect on the promotion of postgraduate training, which is why the effectiveness of many schools' school-enterprise cooperation is not obvious. Therefore, when conducting school-enterprise cooperation, it should be implemented at a substantive level, allowing enterprises to truly participate in the formulation of graduate training programs, and truly assisting graduate education to get rid of the disconnection between teaching and practice. The deepening of school-enterprise cooperation can also enable enterprises to have a higher-quality talent pool, laying a foundation for the sustainable development of enterprises.

In addition, in the school-enterprise cooperative teaching model, both schools and enterprises need to work together to improve the effectiveness of cooperation. In actual cooperation, many companies have not shown sincerity and 
enthusiasm for cooperation. Companies blindly want to select high-quality talents from schools, but are unwilling to invest energy, resources, and costs in student pre-education. Many companies believe that providing students with prejob training and practical training will consume a lot of energy and labor costs, but the effect of student training cannot be guaranteed, and the students may not be employed in the company after training. The uncertainty of this result Many companies are unwilling to take risks in school-enterprise cooperation, and their investment will be reduced accordingly. In response to this problem, on the one hand, companies can increase their own attractiveness to talents through factors such as corporate culture penetration, salary and benefits, and development prospects, and increase the intention of graduate students to join corporate teams. On the other hand, it is possible to sign the corresponding account guarantee mechanism when starting school-enterprise cooperation to reduce the risk of brain drain that enterprises need to bear.

When colleges and universities launch school-enterprise cooperation in postgraduate education, they should focus on exploring new modes of cooperation, give full play to the role of school-enterprise cooperation in improving graduate students' practical ability, and formulate the most scientific school-enterprise cooperation based on regional economic characteristics and the status quo of graduate professional fields The operating mechanism enables the school-enterprise cooperation to advance in a more orderly manner, and also strengthens the closeness between the school and enterprise.

\section{Concluding remarks}

School-enterprise cooperation has a great promotion effect on both enterprises and schools, and it is more conducive to schools to grasp the needs of society and enterprises, so as to train graduate students in a targeted manner, so that the comprehensive quality of graduate students can meet the requirements of enterprises. For enterprises, school-enterprise cooperation can cultivate more outstanding talents, introduce advanced technology and high-quality talents for enterprises, and thus help enterprises achieve faster development. Therefore, in the field of graduate education, the school-enterprise cooperative education model is widely used to continuously optimize the quality of graduate education and cultivate innovative and comprehensive graduate students

\section{References}

1. Zhang Jun, Cui Zhiyuan. Research on the school-enterprise cooperation training model for postgraduates majoring in finance and economics[J]. Management Observation, 2020(21):137-139.

2. Baixuehua. Cultivation of graduate students' innovative ability under the background of "Internet +" [J]. New Curriculum Research, 2020(21): 41-42.

3. Yu Limei, Tan Minhua, Feng Weihua, Chen Haiguang, Zeng Xiaofang. Exploration of the construction of a practice base for joint training of graduate students between schools and enterprises[J]. Henan Chemical Industry, 2020, 37(06): 65-67. 